Panalungtik: Jurnal yang memuat kajian gagasan dan informasi tentang budaya dan kehidupan masa lalu e-ISSN: 2621-928X

Vol. 1(1) , Juli 2018, pp 27-40 DOI : https://doi.org/10.24164/pnk.v1i1.1

\title{
NILAI PENTING KOMPLEKS MAKAM SYEH TUBAGUS ABDULLAH DAN BALUNG TUNGGAL DI KECAMATAN PURBARATU, KOTA TASIKMALAYA
}

\section{Important Value of Tomb Complex of Syeh Tubagus Abdullah And Balung Tunggal in Kecamatan Purbaratu, Kota Tasikmalaya}

Endang Widyastuti dan Oerip B Boedi

\author{
Balai Arkeologi Jawa Barat \\ Jl. Raya Cinunuk Km. 17 Cielunyi Bandung \\ E-mail: endang.widyastuti@kemdikbud.go.id \\ E-mail: obboedi@yahoo.co.id \\ Naskah diterima 6 Maret 2018 - Revisi 6 Juni 2018 \\ Disetujui terbit 27 Juli 2018 - Diterbitkan secara online 31 Juli 2018
}

\begin{abstract}
Site of the tomb of Sheikh Tubagus Abdullah is located in Sukasih Village, Purbaratu, Tasikmalaya City. Sheikh Tubagus Abdullah has historically been regarded as an important figure in the spread of Islam in Purbaratu and beyond. As a site, the complex of this tomb has an important meaning for the community. One benchmark of this measure is to weight the importance of the site. Based on this study aims to obtain a historical picture and the importance of the complex of the tomb. The study begins with collecting data in the field of observation of material objects and interviews with resource persons. Data analysis uses quality parameters and important value parameters. Based on the results of data analysis obtained conclusion that this site has a high value of high importance.
\end{abstract}

Keywords: important value, complex of tomb of Sheikh Tubagus Abdullah, Purbaratu, Tasikmalaya City

\begin{abstract}
Abstrak
Situs kompleks makam Syeh Tubagus Abdullah terletak di Desa Sukasih, Purbaratu, Kota Tasikmalaya. Syeh Tubagus Abdullah secara historis dianggap sebagai tokoh yang penting adalam penyebaran agama Islam di Purbaratu dan sekitarnya. Sebagai situs, kompleks makam ini mempunyai arti yang penting bagi masyarakat. Salah satu tolok ukuran hal ini adalah dengan melakukan pembobotan tentang nilai penting dari situs. Berdasarkan hal tersebut kajian ini bertujuan memperoleh gambaran sejarah dan nilai penting dari kompleks makam tersebut. Kajian diawali dengan mengumpulkan data di lapangan berupa pengamatan terhadap objek material dan wawancara dengan narasumber. Analisis data menggunakan parameter kualitas dan parameter nilai penting. Berdasarkan hasil analisis data diperoleh simpulan bahwa situs ini mempunyai bobot nilai penting yang tinggi.
\end{abstract}

Kata kunci: nilai penting, kompleks makam Syeh Tubagus Abdullah, Purbaratu, Kota Tasikmalaya

\section{PENDAHULUAN}

Untuk memenuhi kebutuhan hidupnya manusia berinteraksi dengan alam. Interaksi tersebut telah melahirkan sinergi antara manusia dengan alam dan pada akhirnya telah mendorong kreativitas manusia yang beraneka ragam. Interaksi manusia dan lingkungan alam pada awalnya, semata-mata untuk memenuhi kebutuhan hidupnya, namun sesuai dengan perjalanan waktu, interaksi 
tersebut telah menghasilkan karya budaya yang memiliki nilai bagi sejarah, kebudayaan, ilmu pengetahuan, dan agama.

Dalam mengeksplorasi lingkungan, manusia menciptakan alat sederhana, agar dapat memenuhi kebutuhan hidup baik material maupun spiritual. Jejak-jejak hasil eksplorasi yang berupa karya budaya masa lampau dapat ditemukan dan terekam pada sisasisa budaya atau biasa disebut sebagai artefak yang ditinggalkan. Hasil kreativitas manusia masa lampau dalam kerangka arkeologis dapat berupa benda bergerak yang lazim disebut artefak maupun benda tidak bergerak, seperti situs, bangunan, monumen, maupun fitur, sesuai dengan kondisi dan sumberdaya alam yang tersedia saat itu.

Kawasan

Tasikmalaya

mempunyai sejarah budaya sejak masa prasejarah hingga masa kolonial. Beberapa sumber sejarah ada yang menyebut-nyebut daerah Tasikmalaya, misalnya pada naskah Amanat Galunggung. Naskah ini menggunakan bahasa Sunda kuna dan aksara Sunda, pernah dikaji oleh Saleh Danasasmita (1987), yang dikompilasikan dalam "Sewaka Darma, Sanghyang Siksakandang Karesian, Amanat Galunggung". Naskah "Amanat Galunggung" berisi ajaran moral, antara lain disebutkan bahwa kabuyutan harus dipertahankan. Raja yang tidak bisa mempertahankan kabuyutan di wilayah kekuasaannya lebih hina dibandingkan dengan kulit musang yang terbuang di tempat sampah. Dengan demikian, dalam tata politik masa lalu, pusat-pusat kegiatan intelektual dan keagamaan memiliki kedudukan yang sangat penting. Kabuyutan merupakan salah satu pilar yang menopang integritas negara sehingga tempat itu dilindungi oleh raja, bahkan dianggap sakral.

Tasikmalaya memiliki sumber daya alam yang sangat mendukung untuk berdirinya suatu lokasi/hunian manusia pada masa lampau. Dengan keberadaan Situs Lingga-Yoni di Gunung Cikabuyutan, Kecamatan Indihiang, Kota Tasikmalaya, menunjukkan adanya indikasi bahwa di wilayah Kota Tasikmalaya terdapat tinggalan budaya yang memiliki nilai arkeologis, baik dilihat dari jenis, sebaran, fragmen budaya, dan sejarah masa lalu. Fragmen budaya tersebut perlu terus digali, diidentifikasi, diklasifikasikan sehingga dapat dimanfaatkan untuk perkembangan dan dinamika masyarakat masa kini.

Sebagai daerah yang cukup besar potensi arkeologis, di Kota Tasikmalaya telah dilaksanakan penelitian-penelitian dan kajian arkeologis. Pada tahun 2005, arca-arca masa klasik telah dikaji oleh Endang Widyastuti. Kajian tersebut digabungkan dengan kajian ikonografis di wilayah Kabupaten Ciamis serta Kabupaten Tasikmalaya (Widyastuti, 2005). Pada tahun 2006, tim Balai Arkeologi Bandung telah melakukan penelitian tentang perkembangan pusatpusat pemerintahan Kabupaten Tasikmalaya. Kota Tasikmalaya sebelum menjadi wilayah administratif sebuah kota merupakan bagian dari kabupaten Tasikmalaya (Boedi, 2006). Selanjutnya pada tahun 2008 tim Balai Arkeologi Bandung meneliti 
permukiman etnis Cina pada awal abad XX (Shanti, 2008). Pada tahun 2012 dilaksanakan penelitian di Situs Indihiang dengan fokus pada bangunan suci dan lingkungannya (Widyastuti, 2012). Penelitian di situs Indihiang dilanjutkan lagi pada tahun 2017 dengan fokus penelitian pada arsitektur bangunan suci di Indihiang (Rusyanti, 2017).

Berdasarkan uraian di atas maka Cagar Budaya tidak bergerak yang berada di wilayah Kota Tasikmalaya perlu diteliti dan dikaji sehingga dapat didata, dilestarikan, dan dimanfaatkan untuk kepentingan ilmu pengetahuan, budaya dan dinamika sosial masyarakat Kota Tasikmalaya. Kompleks makam Syeh Tubagus Abdullah merupakan salah satu situs di wilayah Kota Tasikmalaya. Bagi sebagian masyarakat Kota Tasikmalaya, tokoh utama yang dimakamkan di lokasi ini mempunyai arti yang penting. Tokoh dimaksud adalah Syeh Tubagus Abdulah yang merupakan penyebar agama Islam di daerah ini.

Terkait dengan keberadaan makam dan riwayat yang berkembang di tengah masyarakat, pada tanggal 1 4 Desember 2015 telah dilakukan Kegiatan Kajian Benda Cagar Budaya. Dalam kegiatan tersebut dilakukan pendataan lapangan di kompleks makam Syeh Tubagus Abdullah. Berdasarkan latar belakang yang ada terdapat permasalahan yang perlu diungkap, yaitu

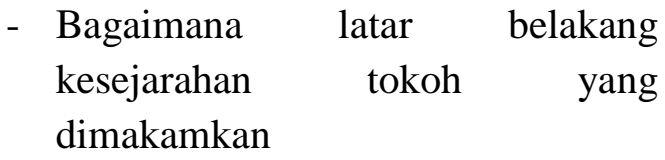

- Bagaimana potensi dan kondisi situs kompleks makam Syeh Tubagus Abdullah

Sehubungan dengan hal tersebut, penelitian dimaksudkan untuk mengungkap permasalahan tersebut. Dengan demikian akan diketahui latar belakang sejarah Syeh Tubagus Abdullah serta potensi kearkeologian kompleks makam Syeh Tubagus Abdullah dan sekitarnya.

Masalah dan tujuan tulisan ini didasari adanya pemikiran bahwa aktivitas manusia masa lampau meninggalkan jejak dalam berbagai bentuk. Salah satunya adalah tinggalan material atau tinggalan arkeologis. Tinggalan arkeologis pada dasarnya dibagi menjadi tiga jenis, yaitu artefak, ekofak, dan fitur. Tinggalan-tinggalan ini berada di suatu wilayah atau kawasan yang disebut dengan situs dan/atau kawasan situs. Situs beserta kandungan data di dalamnya merupakan data penting dan mempunyai manfaat bagi berbagai keperluan. Mengingat arti pentingnya maka kajian dan nilai penting suatu situs harus dilakukan.

\section{METODE}

Sesuai dengan permasalahan yang ada, dalam penelitian ini diterapkan tipe penelitian eksploratif dan deskriptif dengan mengikuti pola penalaran induktif. Metode eksploratif dilakukan berlandaskan pada seluruh data guna mempertajam permasalahan. Setelah permasalahan munculsecara jelas dilakukan pendeskripsian. Pelaksanaan penelitian tidak terbatas pada pengumpulan data, melainkan 
meliputi analisi dan interpretasi data (Gibbon, 1984: 80; Sharer dan Ashmore, 1979: 486). Pada dasarnya metode yang dilaksanakan meliputi tiga tingkat yaitu tingkat observasi, berusaha mengumpulkan data dengan teknik survei lapangan; tingkat deskripsi yaitu mengolah data dengan metode analisi khusus dan kontekstual; dan tingkat eksplanasi yaitu berusaha menafsirkan data sehingga tujuan penelitian tercapai.

Pengumpulan data dilakukan dengan cara pengamatan langsung di lapangan. Selain itu juga diusahakan untuk mendapatkan data sejarah lokal. Data yang bersifat etno-histori ini diperoleh melalui wawancara terhadap tokoh setempat yang dianggap mengetahui latar belakang sejarah tokoh maupun keturunan tokoh yang dimaksud.Pada kesempatan tersebut dilakukan wawancara kepada 2 narasumber, yaitu Tubagus Oom Abdurrahman (68 th, DKM Masjid Agung Tasikmalaya) dan H. Uce Syarif Hidayat (63 th, Ketua Dewan Masjid Kecamatan Purbaratu) sebagai keturunan dari Syeh Tubagus Abdullah.

Setelah data dikumpulkan langkahselanjutanya adalah dengan menilai potensi situs dengan menggunakan parameter yang diajukan oleh Schiffer dan Gummerman. Parameter yang dimaksud adalah parameter kualitas dan parameter nilai penting. Berdasarkan analisis tersebut diperoleh gambaran dan simpulan tentang potensi sumber daya arkeologis situs.

\section{HASIL DAN PEMBAHASAN}

Kota Tasikmalaya secara geografis terletak di antara $108^{\circ} 08^{\prime} 38^{\prime \prime}$ - $108^{\circ} 24^{\prime} 02^{\prime \prime}$ Bujur Timur dan $7^{\circ} 10^{\prime} 00^{\prime \prime}$ 7026'32" Lintang Selatan. Perbatasan wilayahnya adalah di sebelah utara berbatasan dengan Kabupaten Tasikmalaya dan Kabupaten Ciamis, sebelah barat berbatasan dengan Kabupaten Tasikmalaya, sebelah selatan berbatasan dengan Kabupaten Tasikmalaya, dan di sebelah timur berbatasan dengan kabupaten Tasikmalaya dan Kabupaten Ciamis (http://www.jabarprov.go.id/index.php/ pages/id/1065). Penggunaan lahan di Kota Tasikmalaya didominasi oleh kegiatan di sektor pertanian seluas $73.47 \%$, yang mencakup penggunaan lahan untuk sawah seluas $36.54 \%$; tegal/kebun seluas $12.51 \%$; ladang huma seluas 3064; hutan rakyat seluas $3.64 \%$, hutan negara seluas $2.18 \%$ dan kolam/empang seluas 3.9\%. Komoditi unggulan kota ini yaitu perkebunan dengan komoditinya adalah Kelapa, Teh, Cengkeh, Kopi dan Aren (https://tasikasik.com/inilah-limakomoditas-unggulan-di-tasikmalaya/)

Tasikmalaya secara historis merupakan kelanjutan dari Kabupaten Sukapura yang mulai eksis pada masa Mataram di bawah kepemimpinan Sultan Agung. Sebelum itu, di Tasikmalaya pernah berdiri satu komunitas yang sudah mengenal institusi pemerintahan walau hanya kecil. Ibukota pemerintahan Kabupaten Sukapura mengalami beberapa kali perpindahan. Ketika Kota Tasikmalaya sekarang belum merupakan ibukota, hanya merupakan permukiman kecil setingkat kelurahan yang disebut Tawang. Kota kecil ini merupakan pusat Kota Tasikmalaya ketika sudah 
berkembang menjadi kota besar (Marlina, 2000: 92-110).

Arti nama Tasikmalaya sering dihubungkan dengan kondisi alam. Salah satu pendapat mengatakan, Tasikmalaya berasal dari kata tasik dan malaya. Tasik berarti danau, laut atau air yang menggenang; dan malaya merupakan deretan pegunungan di pantai Malabar, India. Tasikmalaya diartikan sebagai deretan gunung atau bukit bagaikan air laut. Pendapat lain mengatakan bahwa Tasikmalaya berasal dari kata keusik ngalayah yang artinya banyak pasir di mana-mana (Marlina, 2000: 91-92). Gambaran kondisi alam yang melatari nama Tasikmalaya berkaitan dengan kondisi Tasikmalaya yang berada di kaki Gunung Galunggung.

Beberapa bukit kecil yang terdapat di Tasikmalaya merupakan hasil letusan Gunung Galunggung yang terjadi pada ribuan tahun yang lalu. Gunung Galunggung merupakan salah satu gunungapi aktif tipe A berlokasi di sebelah barat laut Kota Tasikmalaya. Letusan yang terakhir cukup menarik dan menghebohkan dunia dengan beberapa kali letusan secara periodik hampir setiap minggu selama 9 bulan, tepatnya mulai hari Senin 5 April 1982 sampai dengan Februari 1983. Sebelum letusan 1983, tercatat ada tiga kali letusan, yaitu pada 1822, 1894, dan 1918. Jauh sebelum letusan 1822, berdasarkan data dan fakta yang ada di lapangan berupa endapan-endapan vulkanik yang membentuk tubuh gunung, juga menunjukan adanya letusan dahsyat. Kawah besar yang berbentuk tapal kuda, menunjukan jejak suatu letusan besar, disertai dengan longsoran vulkanik yang dahsyat. Letusan hebat itu membentuk bukitbukit di sekitar Kota Tasikmalaya yang disebut Bukit Sepuluh Ribu (As'ari, 2018:9;Malik,Http://File.Upi.Edu/Direk tori/Fpips/Jur._Pend._Geografi/195901 011989011_Yakub_Malik/Konservasi_P erbukitan_Sepuluh_Ribu_\%28ten_Thou sand_Hills\%29.Pdf diunduh 14/3/18).

Bukit Sepuluh Ribu (Ten Thousand Hils) tersebar di sebelah tenggara Gunung Galunggung, mengarah hingga Kota Tasikmalaya terutama di sebelah barat laut kota. Bukit itu merupakan onggokan batuan, bagian dari tubuh Gunung Galunggung yang roboh bersamaan dengan terjadinya letusan dahsyat yang terjadi ribuan tahun lalu. Kota Tasikmalaya berada pada kawasan Perbukitan Sepuluh Ribu tersebut. Di sekitar Tasikmalaya ini subur dengan air sehingga banyak sekali kolam-kolam tempat memelihara ikan darat yang sudah menjadi tradisi masyarakat terutama di pedesaan yang selalu ada kolam di halaman rumah.

a. Sejarah Singkat Syeh Tubagus Abdullah

Keterangan mengenai siapa Kyai Haji (K.H.) Tubagus Abdullah, diperoleh dari H. Uce Syarif Hidayat ${ }^{1}$ dan silsilah K.H. Tubagus Abdullah dan keturunannya yang disusun oleh $\mathrm{H}$. Endang Ahmad. Di samping itu, riwayat hidup dan ajaran-ajarannya hingga sekarang masih hidup dalam bentuk

\footnotetext{
${ }^{1}$ H. Uce Syarif Hidayat (63 th, Ketua Dewan Masjid Kecamatan Purbaratu) sebagai keturunan dari Syeh Tubagus Abdullah.
} 
nadoman yang masih dilafalkan dalam acara-acara keagamaan di Kelurahan Sukaasih, Kecamatan Purbaratu, Kota Tasikmalaya. Nadoman tersebut telah ditulis oleh Ustad Adun dalam bentuk huruf Arab Jawi berbahasa Sunda.

Berdasarkan keterangan tersebut diperoleh keterangan bahwa K.H. Tubagus Abdullah atau sering juga disebut Syeh Tubagus Abdullah adalah seorang bangsawan dari lingkungan Kesultanan Banten. Beliau sering juga disebut Eyang Gandrung, karena beliau makan biji gandrung sebagai bahan makanan pokoknya. Disebabkan oleh adanya ketidaksetujuan dengan datang dan berpengaruhnya orang Eropa, terutama Belanda, beliau pergi meninggalkan istana menuju ke arah timur. Dalam perjalanannya, beliau dengan diikuti oleh beberapa pengawalnya. Di daerah Tasikmalaya, beliau sempat singgah dan menetap untuk sementara waktu di Galunggung. Kemudian melanjutkan perjalanan hingga tiba di Kampung Sukabetah.

Kampung terakhir yang didatangi merupakan kampung dengan penduduknya beragama Buddha dan dipimpin oleh seorang pimpinan yang bernama Balung Tunggal. Di daerah ini, K.H. Tubagus Abdullah menetap dan menyebarkan agama Islam. Upaya ini tidak serta mendapat respon positif pada awalnya. Terdapat penolakan hingga terjadi konflik antara K.H. Tubagus Abdullah dengan Balung Tunggal. Akhirnya terjadi adu kesaktian antara keduanya yang dimenangkan oleh K.H. Tubagus Abdullah. Dengan kekalahannya, Balung Tunggal masuk
Islam yang kemudian diikuti oleh masyarakat setempat.

K.H. Tubagus Abdullah menikah dengan Nini Beui, perempuan dari Sindangkasih (sekarang secara administratif masuk wilayah Kabupaten Ciamis, Jawa Barat). Dari pernikahan ini, K.H. Tubagus Abdullah mempunyai dua putra, yaitu Raden Toyib Bangsapraja dan K.H. Tubagus Muhammad Abdun. Raden Toyib Bangsapraja kemudian menetap di Sumedang, sedangkan K.H. Tubagus Muhammad Abdun tetap di Tasikmalaya. Keduanya aktif menyebarkan agama Islam. Keturunanketurunan K.H. Tubagus Muhammad Abdun banyak yang menjadi pengasuh pondok-pondok pesantren di daerah Tasikmalaya hingga sekarang.

b. Gambaran Situs

Kompleks makam Syeh Tubagus Abdullah terletak di Blok Meunggeur, Kampung Sukabetah, Kelurahan Sukaasih, Kecamatan Purbaratu, Kota Tasikmalaya Secara astronomis keletakan kompleks makam adalah sebagai berikut, $07^{\circ} 19^{\prime} 05,2^{\prime \prime}$ lintang selatan (LS) dan 108 ${ }^{\circ} 14^{\prime} 59,6^{\prime \prime}$ bujur timur (BT) dengan ketinggian 341 $\mathrm{m}$ dari permukaan laut (dpl). Lokasi kompleks makam Syeh Tubagus Abdullah berada pada lahan seluas sekitar 8 ha, dikelilingi tumbuhan tropis dan pemukiman penduduk serta persawahan di beberapa bagian.

Pengamatan yang dilakukan di lokasi menunjukkan adanya indikasi sebagai lokasi pemukiman. Indikasi pemukiman tersebut terlihat dari adanya 
benteng tanah dan parit buatan di sisi selatan. Benteng tanah dan parit tersebut sekarang terpotong di bagian tengah yang dipergunakan untuk jalan menuju makam.
Kompleks makam tersebut berada di sisi timur Ci Loseh berjarak sekitar $70 \mathrm{~m}$ dan berada sekitar $280 \mathrm{~m}$ di sebelah barat daya pertemuan $\mathrm{Ci}$ Loseh dan Ci Tanduy. Lokasi kompleks

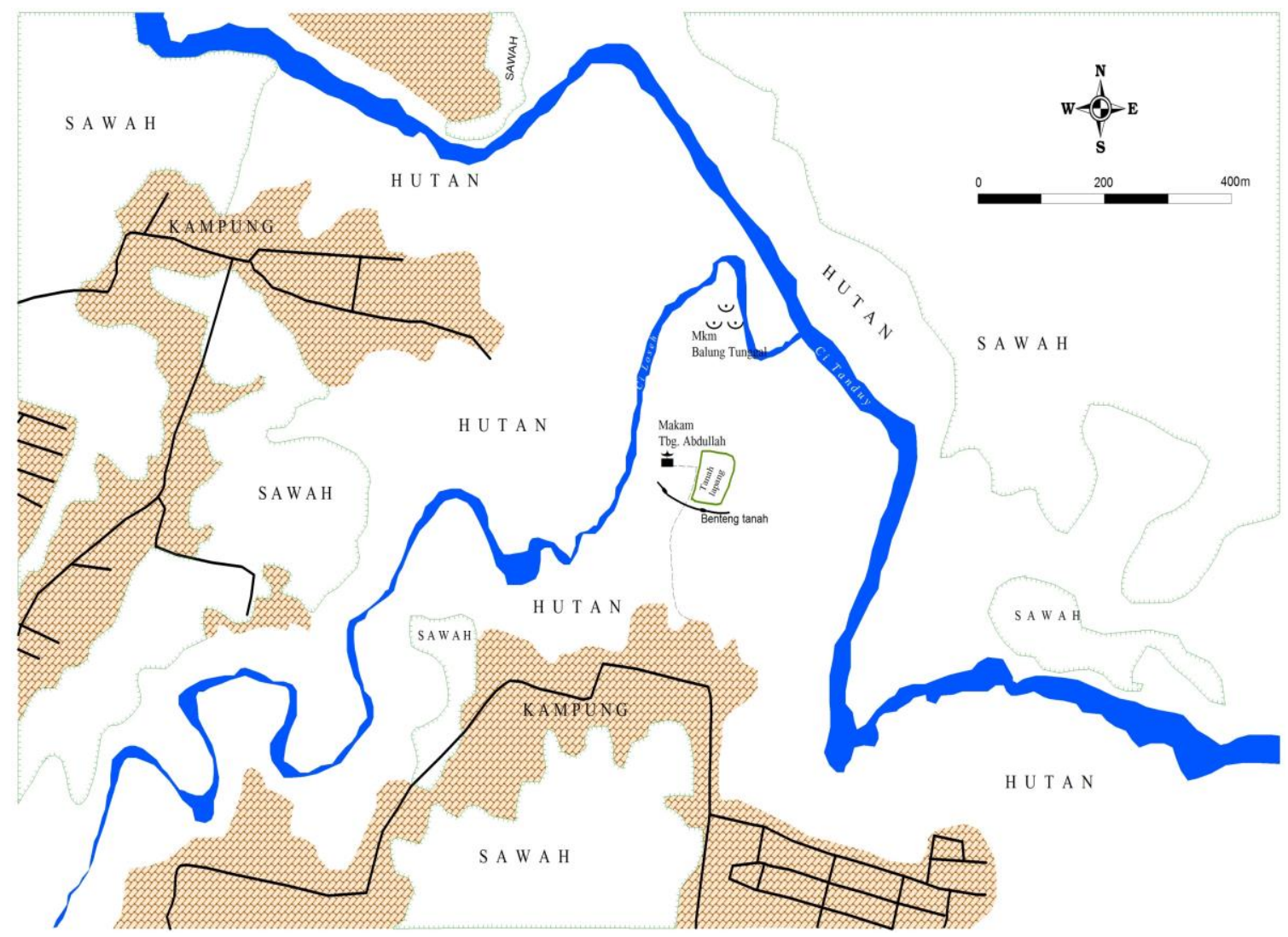

Gambar 1. Situasi Lingkungan Kompleks Makam Tubagus Abdullah (Disalin dari google maps dengan modifikasi)

Kondisi sekarang di sebelah utara benteng tanah tersebut sudah diratakan untuk membuat lapang bola. Pengamatan di lapangan menemukan 4 keping fragmen keramik di areal tanah lapang tersebut. Menurut keterangan penduduk pada waktu meratakan lahan untuk lapang bola ditemukan sejumlah arang bekas kayu yang terbakar. makam berada pada lahan yang meninggi ke arah utara dan barat, dengan jalan masuk berada di sisi selatan. Kompleks makam dibagi menjadi tiga tingkatan/undakan lahan. Ketiga undakan tersebut sebagai berikut (Boedi, 2012: 127; Abrianto et all, 2012). 


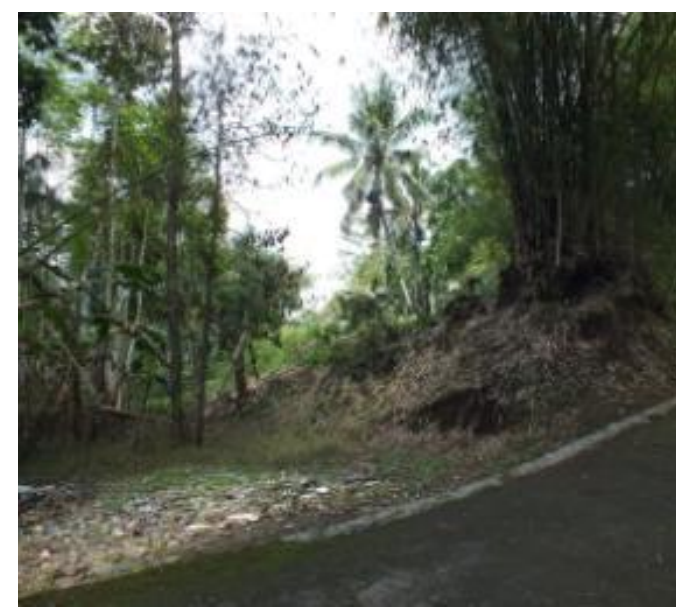

Gambar 2. Benteng tanah dan parit dengan jalan di bagian tengah menuju makam (Sumber: Dokumen Balai Arkeologi Bandung, 2015)

Undakan I merupakan undakan paling bawah berbentuk persegi panjang. Bagian tepi undakan I ditandai dengan tatanan batu andesit tidak dibentuk. Pada undakan pertama ini terdapat 16 makam dengan orientasi utara - selatan. Keenambelas makam tersebut belum diketahui siapa tokoh yang dimakamkan. Makam berupa susunan batu-batu andesit tidak dibentuk. Penanda makam (nisan) juga terbuat dari batu andesit yang tidak dibentuk.

Undakan II berada lebih tinggi dari undakan I, berbentuk persegi panjang namun berukuran lebih kecil dari undakan I. Di antara undakan I dan undakan II dibatasi dengan batu andesit yang tidak dibentuk. Terdapat 9 makam yang tidak dikenal pada undakan II ini. Makam-makam tersebut berorientasi utara - selatan. Penanda makam terbuat dari batu andesit yang tidak dibentuk.

Undakan III berada sedikit lebih tinggi dari undakan II. Kondisi sekarang undakan III ini telah berpagar tembok

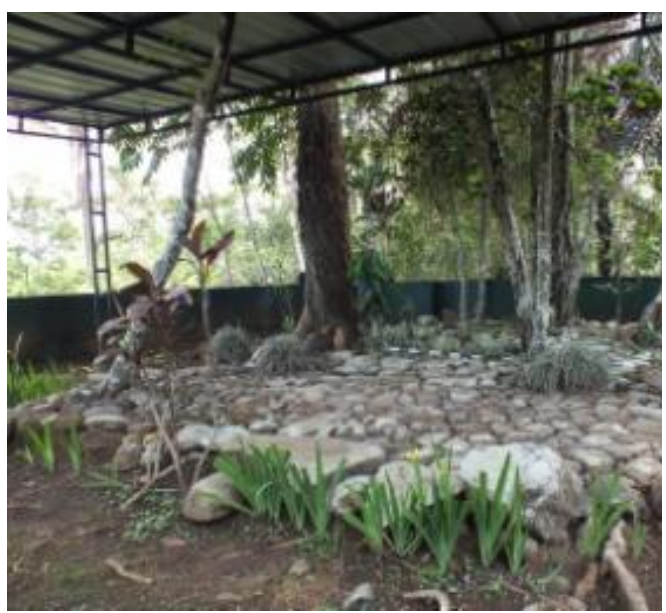

Gambar 3. Undakan III dengan makam Eyang Gandrung dan Nini Beui

(Sumber: Dokumen Balai Arkeologi Bandung, 2015)

setinggi sekitar $1 \mathrm{~m}$. Di dalam pagar tersebut terdapat tatanan batu andesit yang disusun membentuk bidang datar berbentuk persegi. Di atas susunan batu tersebut terdapat 2 makam berorientasi utara - selatan. Kedua makam tersebut ditandai dengan jajaran batu andesit tidak dibentuk dengan penanda makam

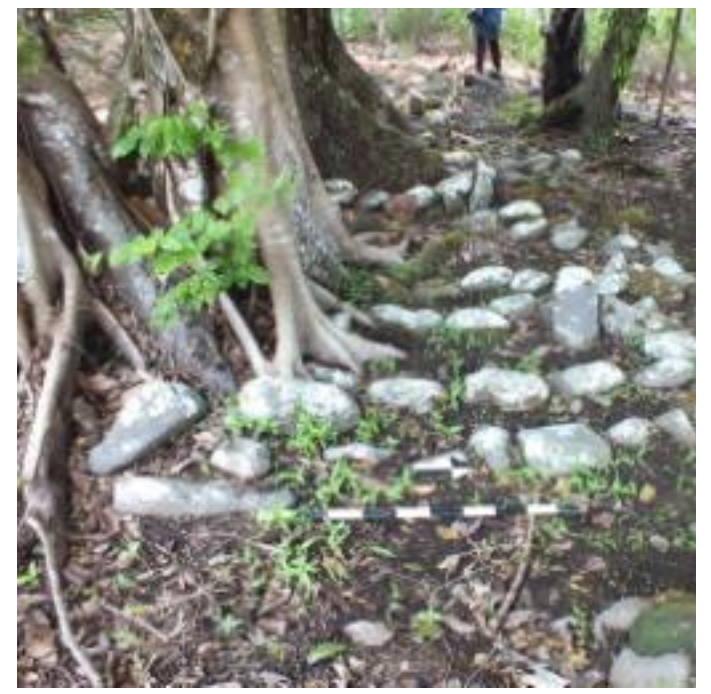

Gambar 4. Makam Balung Tunggal (Sumber: Dokumen Balai Arkeologi Bandung, 2015)

terbuat dari batu andesit juga. Kedua makam tersebut adalah makam Eyang Gandrung dan Nini Beui. Sekarang ini 
di bagian barat undakan III terdapat bangunan cungkup semi permanen yang dipergunakan untuk beristirahat para peziarah.

Berjarak sekitar $240 \mathrm{~m}$ di sebelah timur laut makam Syeh Tubagus Abdullah terdapat Makam Balung Tunggal. Makam berada pada lahan datar dengan pohon-pohon besar yang tumbuh di sekelilingnya. Di lokasi ini terdapat beberapa makam lain selain makam Balung Tunggal. Seluruh makam tersebut berorientasi utaraselatan. Selain makam Balung tunggal, belum diketahui tokoh yang dimakamkan di lokasi tersebut. Bentuk serta penanda makam berupa susunan batu andesit yang tidak dibentuk.

\section{PEMBAHASAN}

Sebagai suatu sumberdaya arkeologi arah pengelolaan suatu situs arkeologi bergantung pada dua hal pokok, yaitu potensi dan permasalahannya. Aspek potensi meliputi parameter kualitas dan nilai penting yang disandangnya. Sedang aspek permasalahan meliputi gejalagejala yang menyebabkan atau mempercepat kerusakan atau kepunahan tinggalan di situs tersebut, baik yang diakibatkan oleh proses alam maupun manusia (Kusumohartono, 1992/1993: 9). Dalam kegiatan kajian kali ini hanya akan dilihat potensi situs kompleks makam Syeh Tubagus Abdullah dan makam Balung Tunggal.

Potensi suatu sumberdaya arkeologi, menurut Schiffer dan Gumerman (1977) dalam telaahnya atas parameter kualitas dan nilai penting dapat dijabarkan sebagai berikut.
Matriks Parameter Potensi Situs Arkeologi

\begin{tabular}{|l|l|}
\hline Parameter Kualitas & \multicolumn{1}{|c|}{$\begin{array}{c}\text { Parameter Nilai } \\
\text { Penting }\end{array}$} \\
\hline - Besaran & - Keilmuan \\
- Sumber & - Kesejarahan \\
informasi & Kelangkaan/ \\
keunikan & - Kemasyarakatan \\
- Keterawatan & - Keetnikan \\
\hline \multicolumn{2}{|c|}{ Penyajian informasi mengenai } \\
\hline
\end{tabular}

aspek kualitas dan nilai penting sumberdaya arkeologi di situs kompleks makam Syeh Tubagus Abdullah dan makam Balung Tunggal dapat ditetapkan melalui prosedur pembobotan dalam tiga kategori yaitu baik atau tinggi (3), sedang (2), dan buruk atau rendah (1).

Situs kompleks makam Syeh Tubagus Abdullah dan makam Balung tunggal pada parameter kualitas dari segi besaran termasuk dalam kategori tinggi (3) yaitu sekitar 8 hektar. Dari segi sumber informasi, terutama informasi ilmiah, mempunyai bobot tinggi (3). Hal ini ditunjukkan dengan adanya fitur benteng serta parit buatan, makam, dan beberapa artefak keramik yang menunjukkan adanya pemukiman pada masa lalu. Ditinjau dari aspek kelangkaan, situs yang dilengkapi dengan benteng dan parit di wilayah Kota Tasikmalaya termasuk tinggi (3). Sampai saat ini situs pemukiman dengan benteng tanah dan parit seperti tersebut belum ditemukan di wilayah ini.Sedang dari aspek keterawatan situs ini termasuk sedang (2). Meskipun di situs ini mempunyai juru kunci, tetapi 
hanya sebatas mengurusi makam saja. Hal tersebut mengakibatkan data mengenai pemukiman yang lebih mendalam sulit untuk diperoleh. Sebagai contoh, yaitu dengan diratakannya lahan yang sekarang menjadi tanah lapang menjadikan data mengenai pemukiman sudah tidak dapat dilacak lagi di lokasi tersebut.

Pada parameter nilai penting penilaian ditujukan pada seberapa besar manfaat bagi keilmuan, kesejarahan, kemasyarakatan, dan keetnikan. Ditinjau dari segi keilmuan, khususnya arkeologi situs ini bernilai cukup tinggi (3). Keberadaan situs tersebut bagi kajian arkeologi sangat penting. Hal ini selain karena cukup beragamnya tinggalan yang ada, di Kota Tasikmalaya khususnya dan Jawa Barat pada umumnya situs pemukiman yang dilengkapi dengan benteng tanah dan parit termasuk langka. Ditinjau dari segi kesejarahan situs ini juga bernilai tinggi (3), khususnya untuk sejarah lokal setempat. Tokoh yang dimakamkan di lokasi tersebut dipercaya sebagai cikal bakal/sesepuh dan sebagai penyebar agama Islam di kawasan setempat. Segi kemasyarakatan situs ini mempunyai nilai tinggi (3). Sebagai tokoh yang dianggap cikal bakal kawasan tersebut, keterkaitan masyarakat dengan tokoh yang dimakamkan cukup erat.Sedang dari segi keetnikan, situs ini juga bernilai tinggi (3). Syeh Tubagus Abdullah yang diceritakan berasal dari Banten dalam pengembaraannya pernah singgah di Sumedang sebelum menetap di lokasi tersebut. Dengan demikian, peziarah ke makam tersebut tidak terbatas dari masyarakat sekitar saja, namun juga datang dari Banten dan Sumedang. Di samping itu, beliau menikahi penduduk setempat. Hal ini menunjukkan tidak ada perbedaan antara pendatang dari Banten dengan penduduk setempat.

Berdasarkan langkah-langkah pembobotan tersebut diperoleh gambaran sebagaimana matriks berikut.

Matriks Bobot Potensi Situs

\begin{tabular}{|l|l|l|l|}
\hline \multicolumn{2}{|c|}{ Parameter Kualitas } & \multicolumn{2}{c|}{$\begin{array}{c}\text { Parameter Nilai } \\
\text { Penting }\end{array}$} \\
\hline Segi & & Segi & \\
\hline Besaran & 3 & Keilmuan & 3 \\
Sumber & 3 & Kesejarahan & 3 \\
Informasi & & Kemasyaraka & \\
Kelangkaan/keun & 3 & tan & 3 \\
ikan & 2 & Keetnikan & 3 \\
Keterawatan & & & \\
\hline
\end{tabular}

Berdasarkan pembobotan dengan hasil yang terlihat pada matriks di atas dapat disimpulkan bahwa potensi sumberdaya arkeologi situs kompleks makam Syeh Tubagus Abdullahdan Makam Balung tunggal termasuk dalam kategori tinggi. Pada parameter kualitas mempunyai bobot rata-rata sebesar 2,75. Sedang pada parameter nilai pentingmempunyai bobot rata-rata 3 .

Secara umum kompleks makam Syeh Tubagus Abdullah dan Makam Balung Tunggal sebagai warisan budaya mempunyai fungsi, antara lain a) alat atau media mencerminkan cipta, rasa dan karya leluhur bangsa. Unsur kepribadiannya dapat dijadikan suri tauladan kini dan mendatang dalam rangka membina dan mengembangkan kebudayaan nasional; b) alat atau media yang memberikan inspirasi, aspirasi, 
dan akselerasi dalam pembangunan bangsa, baik material maupun spiritual, sehingga tercapai keharmonisan di antara keduanya; dan c) alat atau media untuk memupuk saling pengertian di kalangan masyarakat dan bangsa serta umat manusia melalui nilai-nilai sosial budaya yang terkandung di dalamnya (Soediman, 1985: 1207).

Suatu unsur penting identitas budaya adalah kesadaran sejarah yang dimiliki bersama suatu bangsa. Kesadaran sejarah itu akan membawa ingatan akan asal usul budaya, peristiwa yang pernah dialami, dan harapan di masa depan (Sedyawati, 1992). Oleh karena itu, pengetahuan tentang masa lampau sangat menjadi kebutuhan manusia berbudaya sehingga mengetahui masa lampau merupakan salah satu hak asasi manusia yang dalam (Mc. Gimsey, 1972: 5).

\section{PENUTUP}

Makam K.H. Tubagus Abdullah meskipun ditengarai sudah mengalami sedikit penambahan pagar dan cungkup, namun masih memiliki nilai penting dari segi sejarah, pendidikan, dan agama khususnya bagi masyarakat Tasikmalaya. Demikian juga dengan makam Balung Tunggal. Tidak terdapat perubahan maupun penambahan pada makam Balung Tunggal, kondisi makam maupun lingkungannya dapat dikatakan masih asli. Makam tersebut memiliki nilai penting sejarah dan agama bagi wilayah Kota Tasikmalaya dan sekitarnya.

Berdasarkan hasil kajian tersebut diperoleh gambaran bahwa tokoh Syeh Tubagus Abdullah merupakan cikal bakal dan tokoh dalam penyebaran Islam di wilayah Purbaratu pada khususnya dan Tasikmalaya pada umumnya. Tinggalan arkeologis yang berkaitan dengan beliau tidak terbatas pada kompleks makam tetapi meliputi areal pemukiman yang dibatasi oleh adanya benteng tanah dan parit buatan yang berada di sebelah selatan kompleks makam. Dugaan tentang areal pemukiman juga didukung dengan adanya temuan 4 keping fragmen keramik Cina dan Eropa.

\section{DAFTAR PUSTAKA}

Abrianto, Octaviadi et al. 2012. Penelitian Arkeologi di Kota Tasikmalaya. Laporan Penelitian. Tasikmalaya: Disparbudpora Kota Tasikmalaya

As'ari, Ruli. 2018. Pengetahuan Dan Sikap Masyarakat Dalam Melestarikan Lingkungan Hubungannya Dengan Perilaku Menjaga Kelestarian Kawasan Bukit Sepuluh Ribu Di Kota Tasikmalaya. Jurnal GeoEco 4 (1), Januari 2018, 918.

Boedi, Oerip Bramantyo. 2006. Perkembangan Kota-kota Pusat Pemerintahan Kabupaten Tasikmalaya. Laporan Hasil Penelitian. Bandung: Balai Arkeologi Bandung

Boedi, Oerip Bramantyo. 2012. Islamisasi di Desa Sukaasih, Purbaratu, Kota Tasikmalaya. Dalam Dr. Heriyanti O. Untoro (ed.). Arkeologi Ruang, Lintas 
Waktu Sejak Prasejarah Hingga Kolonial di Situs-Situs Jawa Barat dan Lampung (123 - 130). Sumedang: Alqaprint Jatinangor.

Danasasmita, Saleh. 1987. Sewaka Darma, Sanghyang Siksa Kanda ng Karesian, Amanat Galunggung. Jakarta: Bagian Proyek Penelitian dan Pengkajian Kebudayaan Sunda (Sundanologi), Direktorat Jenderal Kebudayaan, Departemen Pendidikan dan Kebudayaan

Gibbon, Guy. 1984. Anthropological Archaeology. New York: Columbia University Press

Inilah lima komoditas unggulan di Tasikmalaya. (https://tasikasik.com/inilah-limakomoditas-unggulan-di-tasikmalaya/)

Kusumohartono, Bugie. 1992/1993. Laporan Hasil Penelitian Arkeologi Situs Medowo, Gampingrowo, Tarik, Sidoarjo, Jawa Timur, Tahap V. Departemen Pendidikan dan Kebudayaan, Pusat Penelitian Arkeologi Nasional, Balai Arkeologi Yogyakarta.

Malik, Yakub. Konservasi Lahan Perbukitan Sepuluh Ribu (Ten Thousand Hill) Untuk Lansekap Hutan Kota Dalam Menunjang Ruang Terbuka Hijau (RTH) Di Kota Tasikmalaya (Http://File.Upi.Edu/Direktori/Fpips/Jur._Pend._Geografi/195901011989011Yakub_Malik/Konservasi_Perbukitan_Sepuluh_Ribu_\%28ten_Thousand_Hills $\% 29$. .Pdf ) diunduh 14/3/18

Marlina, Ietje. 2000. Sukapura (Tasikmalaya). Dalam Nina H. Lubis (ed.). Sejarah Kota-kota Lama di Jawa Barat. Bandung: Alqaprint.

Mc. Gimsey, Charles R. 1972. Public Archaeology. New York: Seminar Press.

Profil Daerah Kota Tasikmalaya. (http://www.jabarprov.go.id/index.php/pages/id/1065, Diakses tanggal 13/3/2018)

Rusyanti. 2017. Penelitian Arsitektur Bangunan Suci Indihiang, Tasikmalaya. Laporan Hasil Penelitian Arkeologi. Bandung: Balai Arkeologi Jawa Barat

Schiffer, Michael B dan George J. Gumerman. 1977. Conservation Archaeology, A Guide for Cultural Resource Management. London: Academic Press.

Sedyawati, Edi. 1992. Arkeologi dan Jatidiri Bangsa. Makalah pada Pertemuan Ilmiah Arkeologi VI. Batu, Malang 26 - 30 Juli 1992. Ikatan Ahli Arkeologi Indonesia.

Shanti, Desril Riva. 2008. Permukiman Etnis Tionghoa di Kota Tasikmalaya pada Awal Abad XX. Laporan Hasil Penelitian Arkeologi. Bandung: Balai Arkeologi Bandung

Sharer, Robert J. dan Wendy Ashmore. 1979. Fundamentals of Archaeology. California: The Binjamin/Cumming Publishing

Soediman. 1985. Peranan Arkeologi Dalam Pembangunan Nasional. Dalam Pertemuan Ilmiah Arkeologi III, Ciloto, 23 - 28 Mei 1983. Jakarta: Proyek Penelitian Purbakala, Departemen Pendidikan dan Kebudayaan

Widyastuti, Endang. 2005. Ikonografi Masa Hindu- Budha di Kabupaten Ciamis dan Tasikmalaya, Jawa Barat. Laporan Hasil Penelitian Arkeologi. Bandung: Balai Arkeologi Bandung 
Widyastuti, Endang. 2012. Bangunan Suci di Situs Indihiang, Tasikmalaya. Dalam Dr. Heriyanti O. Untoro (ed.). Arkeologi Ruang, Lintas Waktu Sejak Prasejarah Hingga Kolonial di Situs-Situs Jawa Barat dan Lampung (31 - 42). Sumedang: Alqaprint Jatinangor.

Widyastuti, Endang. 2016. Arsitektur Bangunan Suci Di Situs Indihiang Kota Tasikmalaya. Jurnal Purbawidya 6(1). 19 - 32. DOI : 10.24164/pw.v6i1.186 
Panalungtik Vol.1, No.1, Juli 2018:27-40 